\title{
International Trade Theories and Decision-Making Areas in the Field of Development Strategy
}

\author{
STADNICKI JERZY, OKSANYCH OLEKSANDR \\ Faculty of Management and Computer Modelling \\ Kielce University of Technology \\ Al.Tysiąclecia Państwa Polskiego 7, 25-314 \\ POLAND
}

\begin{abstract}
According to the authors' concept, there are 4 main reasons for conducting international trade: natural and geographical differences between states; differences in production costs in different countries; the effect of specialization on the production of a good with a greater relative advantage; effect of scale of production). These reasons are necessary, but not sufficient for the appearing of international trade, since any of the options for international trade can be implemented only under the conditions of acceptable "distance resistance", the main features of which are technical capabilities, costs, safety and speed of transportation). The article presents the author's concept of choosing a development strategy at the state or corporate levels, according to which the key determinants are distance resistance, nature of interaction with the environment (offensive or defensive) and the model of economic development (resource-based or knowledge-based).
\end{abstract}

Key-Words: International trade, causes of international trade, theories of international trade, resistance to distance, strategy of development

Received: July 28, 2021. Revised: December 15, 2021. Accepted: January 21, 2022. Published: January 25, 2022.

\section{Introduction}

International trade has reached enormous proportions, bringing significant benefits not only to its participants but also to the entire population. At the same time, international trade poses certain threats related to dumping and / or relocation of goods to other countries. In the context of globalization and increasing competition, the problem of choosing a development strategy at the level of the national economy and at the level of enterprises is becoming increasingly important. This requires identifying the causes of international trade and taking them into account when making strategic decisions.

The aim of the article is to substantiate the reasons for international trade and the choice of priorities in the process of forming a strategy for the development of the national economy in the context of globalization, taking into account the resistance of distance, key factors of economic growth and the nature of relations with the global economic environment.
The research used methods of critical analysis and synthesis (generalization) and logical methods, as well as the method of "desk research".

\section{Problem Formulation}

In order to predict trends in international trade and its impact on the socio-economic situation of individual countries since ancient times, attempts are made to explain the causes of international trade, i.e. attempts to create theories of international trade $[5,10,12,13,24,27,29,33,35,36,39]$. Studies of the causes of international trade, which claim to be called theories of international trade, are popular (their number has long exceeded a damn dozen), but this is precisely the situation where quantity has not turned into quality. The fact is that there are actually 4 (four) basic causes of international trade and related theories, and all the others are at best just camouflaged basic.

First, natural and geographical differences between states determine the need (rational, sometimes irrational) in the purchase of necessary goods: natural resources; agricultural raw materials; even any goods produced in another country, which 
gives them a halo of originality. The author of the concept of differences in the criteria of the country of production is Paul Armington, who in the article "Theory of demand for products that differ in place of production" argues that consumers tend to treat identical goods from different countries as different goods [6].

And although such an interpretation cannot be considered rational, it is real. It is known that the basis of prosperity of Greek cities and their colonies has always been trade, but it should be borne in mind that the Mediterranean is generally homogeneous in climate, soil and flora, and therefore could trade effectively not so much as a product as its special qualities. It is believed that the subtle differences in taste of wine and olive oil, the subtle differentiation of shape and decor of ceramic vessels became the basis of prosperity, and the ability to distinguish subtle, tinted properties of objects was rooted in reality - without this skill the very formation of Greek civilization in its special form would be impossible. But in fact a special quality of wine, olive oil and ceramic vessels was the production in another country-policy, although located a few tens of miles.

The existence of such a situation seems to mean that the natural and geographical differences of countries make international trade inevitable, because these differences cannot but exist. However, not everything is so clear: the level of demand (inside and outside the country) for such specific goods at relatively high prices may not be sufficient for profitable production, which, thus, cancels the inevitability of international trade due to natural and geographical differences between states.

It was Adam Smith in the famous work "Wealth of Nations" for the first time argued that the country can have natural advantages due to its climatic characteristics or possession of certain natural resources [37]. Since Adam Smith became the official discoverer of this type of goods, they can rightly be called "Adam Smith-goods". Formally, "Adam Smith-goods" include identical goods, but produced in different countries (because the country is a geographical concept), but since Adam Smith did not even mention them, these goods deserve to be called "Paul Armington-goods", obviously in the "Adam Smith-goods" group.

Secondly, due to various factors, there are differences in production costs in different countries and, if the magnitude of those differences is significant enough, it is appropriate to export the goods from a country of relatively cheap production to a country where production is relatively expensive. We can call them "Adam Smith-good-2", because this scientist is associated with the theory of absolute advantages, according to which the cause of international trade is the difference in costs (Adam Smith reduced all costs to labor costs, which was a "universal currency" in his research) on the production of identical goods in different countries.

Third, David Ricardo argued that international trade could exist even if one country had an absolute advantage in the production of two goods, because it was more profitable for it to focus on the production and export of goods with a greater relative advantage and a good with a smaller relative advantage. to import [30, 7]. Undoubtedly, "David Ricardo-goods" will be the most numerous in the range and volume of international trade. It is worth noting that the "relative advantage" is the ratio of costs in different countries for the production of identical goods, and "greater or lesser relative advantage" refers to the comparison of indicators of "relative advantages" of different goods.

Fourth, the effects of scale of production are also an important cause of international trade [11]. The optimal scale of production, which provides maximum efficiency, often exceeds the demand within a country, which necessitates exports. Even in the absence of other preconditions for international trade, the effect of scale makes international specialization expedient, in which some countries specialize in the production of certain goods (for themselves and for export), and other countries - in the production of other goods (also for themselves and for export). We can call such goods "Paul Krugman-goods", because it is with this scientist (Paul Krugman) associated with the relevant research, which earned the Nobel Prize in Economics for "a new theory of international trade" $[17,18,19]$.

Now that we have an approach to the causes of international trade, we can move on to a brief analysis of other theories of international trade and the justification that they are at best only camouflaged basic. The first theory of international trade is the theory of mercantilism (XV century), according to which a nation becomes richer and more powerful when it exports more than it imports. According to the theory of mercantilism, the positive balance of foreign trade will remain in the country in the form of precious metals, including gold and silver $[14,15]$.

If this approach will be analyzed the aspects of the feasibility of trade, the need for trade between countries appeares at the time, when in other countries you can buy and delive to your country goods, which will be cheaper than its producing in your country, or in another country you can buy and 
delive to your country goods, which never produced for any reason in its own country or produced in insufficient quantities. The accumulation of precious metals can be interpreted as fashion of then times, which allow treat a theory of mercantilism as one of the theories of fashion on precious metals. Precious metals are exported from countries where they will be cheap, to countries where they were more expensive, only due to the influence of these four reasons (or their combinations):

- natural and geographical differences between countries (some countries possessed significant deposit precious metals ("Adam Smith-goods"),

- spatial differentiation of production costs ("Adam Smith-goods"-2),

- the relative advantage in the production of some goods ("David Ricardo-goods"),

- the effect of large-scale production ('Paul Krugman-goods').

A popular theory of international trade is the Heckscher-Olin theory (Heckscher-Olin theory), according to which countries that export products of intensive use of surplus factors and import products of intensive use of deficient factors for them [20, 26]. The provisions of the Heckscher-Olin theory were later "mathematically supported" by Paul Samuelson, who in 1948 "proved the theorem of equalization of prices for factors of production", in accordance with it international trade leads to the payment of absolute and relative prices for homogeneous factors of production. homogeneous capital is capital that has the same productivity and risk; education and productivity; homogeneous land is land with one family, soil condition, etc.) in trading countries $[8,31,32]$.

First on the Heckscher-Olin theory. Countries can export goods that, for various reasons, can be produced cheaper on their territory than on the territory of importing countries. The presence of surplus factors is one of the reasons for the spatial differentiation of production costs, which, according to Adam Smith, is one of the causes of international trade. Therefore, Heckscher-Olin's theory can in no way claim to be the original theory of international trade, because in fact it is completely within the limits of Adam Smith's theory of absolute advantages in the part "Adam Smith-good-2".

Now about the "equalization of prices" for homogeneous factors of production according to Paul Samuelson. What kind of equalization can we talk about if the difference in prices of the same quality of labour in different countries is a constant factor in the socio-economic development of civilization. The price of land of the same quality in different countries can differ dramatically, because, unlike labour, land is not a mobile resource. The same can be said about the price of capital - nonmobile capital of the same quality can differ significantly in price in different countries. And only mobile capital of the same quality can be characterized by a tendency to "equalize prices" in different countries. A brief analysis of the theory of "price equalization" for homogeneous factors of production is general and has no bearing on the causes of international trade, because Paul Samuelson did not claim "his" theory of international trade. Paul Samuelson's mistake of "equalizing prices" for homogeneous factors of production is not surprising against the background of another fundamental mistake of the Nobel laureate: in 1961 he made the absurd assumption that between 1984 and 1997 the Soviet Union would overtake the United States in size of economy.

Raymond Vernon's theory of the international product life cycle, proposed in 1966, states that some products go through a cycle that consists of four stages: implementation, growth, maturity, and decline; the production of these products moves from one country to another depending on the stage of the cycle [41]. At the first stage (implementation) innovations are developed in response to the identified need. As a rule, the main role here belongs to industrialized countries. At the second stage (growth) the country of innovation in parallel with domestic production of a new product can begin its release abroad. In addition, the release of the same product can be started by a foreign competitor, and he can do so with minor changes in the product, bypassing patent protection or purchasing some licenses. The produced products remain almost entirely in the country where the new enterprise was established.

In the third stage (maturity), global demand for a new product begins to level off. The technology of production of a new product becomes so advanced that additional knowledge to reduce costs is no longer so necessary. The product becomes standardized, so its production in a country with a high level of technology loses its meaning. Production of goods is moved to other countries, which can use the already standard technology, reducing the unit cost of production. Lower costs make it possible to increase sales in underdeveloped countries. Finally, in the fourth stage (decline), technology and equipment are so improved that the production of goods no longer requires special skills, and therefore it moves to underdeveloped countries that have a surplus of cheap labour. 
In Raymond Vernon's theory, everything seems logical, but a deeper analysis shows that in fact the reasons for moving production from country to country are not problems with the availability of production technology, but the usual geographical differences of countries (if in some countries it is impossible to produce any benefit lack of the necessary resources, such as skilled labor) or the usual spatial differentiation of production costs. Therefore, the benefits that could be called "Raymond Vernon-benefits" are actually "Adam Smith-benefits" or "Adam Smith-benefits-2".

In 1961, Michael Posner proposed the theory of technological advancement (Theory of Technological Gap), according to which one of the reasons for international trade is technological innovation, which allows an innovator country to obtain a quasi-monopoly on new products and export it profitably and without competition. , importing non-knowledge-intensive products [28]. Over time, the technological gap narrows due to technology transfer, import substitution, and the introduction of alternative technologies in other countries. Then it all starts again: new innovative solutions (not necessarily in the same country) lead to new export-import flows. Although the theory of technological advancement is considered by some scientists to be a branch of the Heckscher-Olin theory, it can rather be called a component of Raymond Vernon's theory in the first stage of the product life cycle (implementation). If the implementation phase is implemented in one country, it is not due to the impossibility of its implementation in another country, but due to the high cost of this in the absence of the necessary resources, especially such as specialized infrastructure and qualified personnel. Non-mobile resources (specialized infrastructure) will need to be created and mobile (qualified personnel) will need to be imported, which will require significant investment costs and a lot of time. Therefore, the potential "Michael Posner-good" is actually "Adam Smith-good-2".

One of the theories of international trade is often called the gravitational model, according to which trade between two countries is directly proportional to the product of their economic potential and inversely proportional to the distance between them $[1,2,3,40]$. In addition to gross domestic product (GDP), the significance of countries' economies is modeled in gravitational equations by population, country area, border length, and so on. It can be agreed that the "force of economic gravity", ie the size of trade between countries depends on the distance between them and the size of their economies, but they do not determine international trade. Gravitational theory to some extent explains the volume of international trade, but not its causes.

Among the theories of international trade, there are those that try to explain it not in terms of production of goods, but in terms of their consumption. One of the first attempts to explain the peculiarities of modern international trade was made by Staffan Linder in 1961, considering the features of technologically new products (refrigerators, televisions) with which American firms entered the European market in the 1950s. [23] He pointed out that although the main inventions underlying the development of these goods were made by Europeans, they were practically embodied in the United States in the form of technologically new goods, which then conquered the foreign market in Europe.

According to Stephen Linder, the wealthy American consumer was more inclined to consume new expensive goods, and as Europeans' living standards rose, new American goods found their way to Europe. Stefan Linder concluded that technologically complex products are created by the firm in response to existing needs, ie primarily to the needs of the domestic market. And only after the expansion of production, after saturation of the domestic market, the firm seeks to capture the external. The firm will enter the foreign market on the basis of goods prepared by it for domestic consumers, therefore, the consumption structure of the importing country should be as similar as possible to the consumption structure of the exporting country. Thus, according to Stefan Linder, not only differences but also similarities between countries can be a prerequisite for trade.

In describing this theory, it should be noted at once that the "rich American consumer" could easily buy technologically new goods even if they were produced in Europe or, as has been the case in recent decades, in Japan, South Korea, or China. It was not the "rich American consumer" at the time, but the well-functioning US economy, which made it possible to produce high-tech products at relatively low cost. We all remember the days when American scientists made many inventions that were the basis for the production of goods in Japan - and not so much for domestic consumption as for export (including the United States). That is, Stefan Linder's theory, when properly analyzed, turns out to be Adam Smith's camouflaged theory of absolute benefits in terms of the benefits gained (resulting in the production and export of Adam Smith-goods-2.). 
A rich country can import goods instead of producing them first for its market and then for export.

\section{Problem Solution}

Thus, as a result of our study it is substantiated that despite the development of scientists over 10 theories of international trade, only four of them are correct and they can be called basic (these are the theories according to which causes of international trade are: 1) natural and demographic differences between countries; 2) differences between production costs in different countries; 3 ) the effect of specialization on the production of goods with a greater relative advantage; 4) the effect of production scale. All other theories are false or camouflaged (consciously or accidentally).

The conclusions obtained as a result of the study are the basis for the classification of goods in international trade by the names of the authors of the basic theories. Goods that are traded due to natural and geographical differences between states can be called " the Adam Smith - goods". Goods that are traded due to the spatial differentiation of production costs are "Adam Smith - good 2". Goods that are traded due to the effects of the country's specialization in the production of goods with a greater relative advantage can be called "David Ricardo - goods." And the goods that are traded between countries due to the effect of the scale of production - are "Paul Krugman - goods".

The existence of four basic causes of international trade presupposes the possibility of the existence of 15 variants of international trade, which can characterize the situation in international trade for a single country or between two countries (Table 1).

Each of the following table. 1 option covers one or more reasons that determine the international trade of a single country or trade between two countries.

For example, for option 1, the reason for international trade is only natural and geographical differences between countries. Similar in content to this option are options 8,12 and 14, which are also characterized by only one reason for international trade, namely: differences in production costs in different countries (option 8), the effect of specialization in the production of goods with a greater relative advantage (option 12), the effect of production scale (option 14). Fundamentally, there are four options where the reason for international trade is only one.

There are as many as six options for the reasons for international trade. For example, option 2 combines reason 1 (natural-geographical differences between countries) and 2 (differences in production costs in different countries), and option 5 - reason 1 and 3 (the effect of specialization in the production of goods with a greater relative advantage), etc. In turn, there are 4 options with the three reasons for international trade, namely: option 3 (reasons 1,2

Table 1. Potential options for international trade by the criterion of its causes

\begin{tabular}{|c|c|c|c|c|}
\hline \multirow{2}{*}{$\begin{array}{c}\text { Options for } \\
\text { trade between } \\
\text { countries }\end{array}$} & $\begin{array}{c}\text { 1) natural and } \\
\text { geographical } \\
\text { differences } \\
\text { between } \\
\text { countries }\end{array}$ & $\begin{array}{c}\text { 2) differences in } \\
\text { production costs in } \\
\text { different countries }\end{array}$ & $\begin{array}{c}\text { 3) the effect of } \\
\text { specialization in the } \\
\text { production of goods } \\
\text { with a greater relative } \\
\text { advantage }\end{array}$ & $\begin{array}{c}\text { 4) effect of } \\
\text { production } \\
\text { scale }\end{array}$ \\
\hline 1 & + & - & - & - \\
\hline 2 & + & + & - & - \\
\hline 3 & + & + & + & + \\
\hline 4 & + & + & + & - \\
\hline 5 & + & - & + & + \\
\hline 6 & + & - & - & - \\
\hline 7 & + & - & - & + \\
\hline 8 & - & + & + & + \\
\hline 9 & - & + & + & - \\
\hline 10 & - & + & + & + \\
\hline 11 & - & + & + & + \\
\hline 12 & - & - & - & + \\
\hline 13 & - & - & - & + \\
\hline 14 & - & + & + & + \\
\hline 15 & + & & + & + \\
\hline
\end{tabular}


and 3), option 7 (reasons 1, 3 and 4), option 11 (reasons 2, 3 and 4) and option 15 (reasons 1, 2 and 4). Obviously, the only option that covers all four causes of international trade is option 4 . Thus, there are 15 options for international trade by the criterion of its causes.

Although combinatorics may offer another option, since the total number of options for the four elements is 16 , this 16th option is a variant of economic autarky that does not involve international trade and is therefore not of interest to us in this article.

It is worth noting that any of the options of international trade can be realized only under conditions of acceptable "distance resistance" (DR) (the main features of which are technical capabilities, costs, safety and speed of transportation). These 4 reasons for international trade (natural and geographical differences between countries; differences in production costs in different countries; the effect of specialization in the production of goods with a greater relative advantage; the effect of scale) are necessary but not sufficient for international trade, because with significant DR production must take place close to the market and focus, obviously, on local resources, as significant DR will be not only for the goods to

be produced, but also for the resources needed to produce these goods.

Only the reduction of DR (primarily due to the development of transport communications) in the presence of at least one cause of international trade activates the potential of international trade, making it possible to remove the place of production of goods from the place of consumption (Table 2). With percetible (average) level of DR there are precondition for international trade, there is a search for places of production by the criterion of minimum total costs for production of goods and its transportation to markets (or transportation of consumers to non-mobile goods) in the appropriate analysis space. The shape and size of the analysis space is influenced by the OB, which, in turn, depends on the properties of the good (suitability for transportation) and the properties of the analysis space itself (availability of transport communications, belonging to a certain customs space, etc.).

With weak or absent DR, there are significant preconditions for international trade, and the search for places of production on the criterion of minimum costs for the production of goods is performed in the space of analysis, usually the whole world. Only in exceptional situations can the form and size of the analysis space depend on the policy of the community of states or an individual state in the field of national security, when restrictions are imposed on the production of strategic products in other countries.

On the situation regarding international trade from table 2 can be said in sectoral, spatial and historical aspects. The sectoral aspect is the dependence of the DR on the characteristics of the good: in the delineated space and time, the DR for different goods will usually be different (the sectoral aspect of the DR is studied by a special science "cargo science"). The spatial aspect of international trade situations depends on the specificity of the area to which the good must be transported from the place of production to foreign markets (or foreign consumers to the place of production of goods in the case of non-mobile goods): one thing when it comes to mountain areas, and it is another matter when it comes to sea space. The historical aspect is the change in time of DR in different industries and spaces, as well as the fact that in general for DR is

Table 2. Reasons for international trade and distance resistance

\begin{tabular}{|c|c|c|c|}
\hline \multirow{2}{*}{$\begin{array}{l}\text { Reasons for } \\
\text { international } \\
\text { trade }\end{array}$} & \multicolumn{3}{|c|}{ Distance resistance (DR) } \\
\hline & Strong DR & Perceptible DR & Weak DR \\
\hline $1,2,3,4$ & $\begin{array}{l}\text { There are no } \\
\text { prerequisites for } \\
\text { international trade, } \\
\text { as production } \\
\text { should be close to } \\
\text { the market }\end{array}$ & $\begin{array}{l}\text { Prerequisites for international trade are, } \\
\text { as it is advisable to produce in places } \\
\text { (within the relevant analysis space) with } \\
\text { a minimum amount of costs for the } \\
\text { production of goods and their } \\
\text { transportation to markets (or } \\
\text { transportation of consumers to non- } \\
\text { mobile goods) }\end{array}$ & $\begin{array}{l}\text { The prerequisites for } \\
\text { international trade are } \\
\text { significant, as it is } \\
\text { advisable to produce in } \\
\text { places with minimal } \\
\text { costs and sell worldwide }\end{array}$ \\
\hline
\end{tabular}

Source: own development 
characterized by a tendency to decrease over time in all spaces and industries. And also the historical aspect is that sometimes new spaces and new industries with their characteristic indicators of DR can appear. An example of such a new industry is the international trade in greenhouse gas emission rights, which is characterized by the complete absence of DR, as such trade does not involve the relocation of material objects.

The choice of the model of economic development of each country is to some extent determined by the influence of the international environment, one of the manifestations of which is the DR. Therefore, when developing a development strategy both at the state level and at the level of enterprises, the indicators of environmental protection must be taken into account. In some cases, they can be crucial.

Of course, DR is not the only factor that determines the priorities of development, its goals and ways to achieve them. It is advisable when choosing a strategy to take into account global trends in economic development, among which are:

- changing the resource model of economic growth in favor of a knowledge-based economy;
- increasing the level of competition in world markets, due to globalization and accelerating the transfer of technological systems and their components.

Taking into account these key determinants makes it possible to form a set of possible areas for choosing the appropriate development strategy at both the corporate and national levels.

A simplified three-dimensional model of this approach is presented in Fig. 1.

The measurement of DR is represented by strong, tangible and weak levels.

The measurement of the development model involves the possibility of choosing between the classical resource model, the model of the transition type and the model of the economy, which bases its development on knowledge. The basic growth factor in the case of choosing a resource model is the use of any resources [38]. Instead, in the case of a knowledge-based economy, a key factor in development is the ability of the economy to generate and effectively use new knowledge in its various forms (formalized and informal, implicit and explicit, "hard" and "soft").

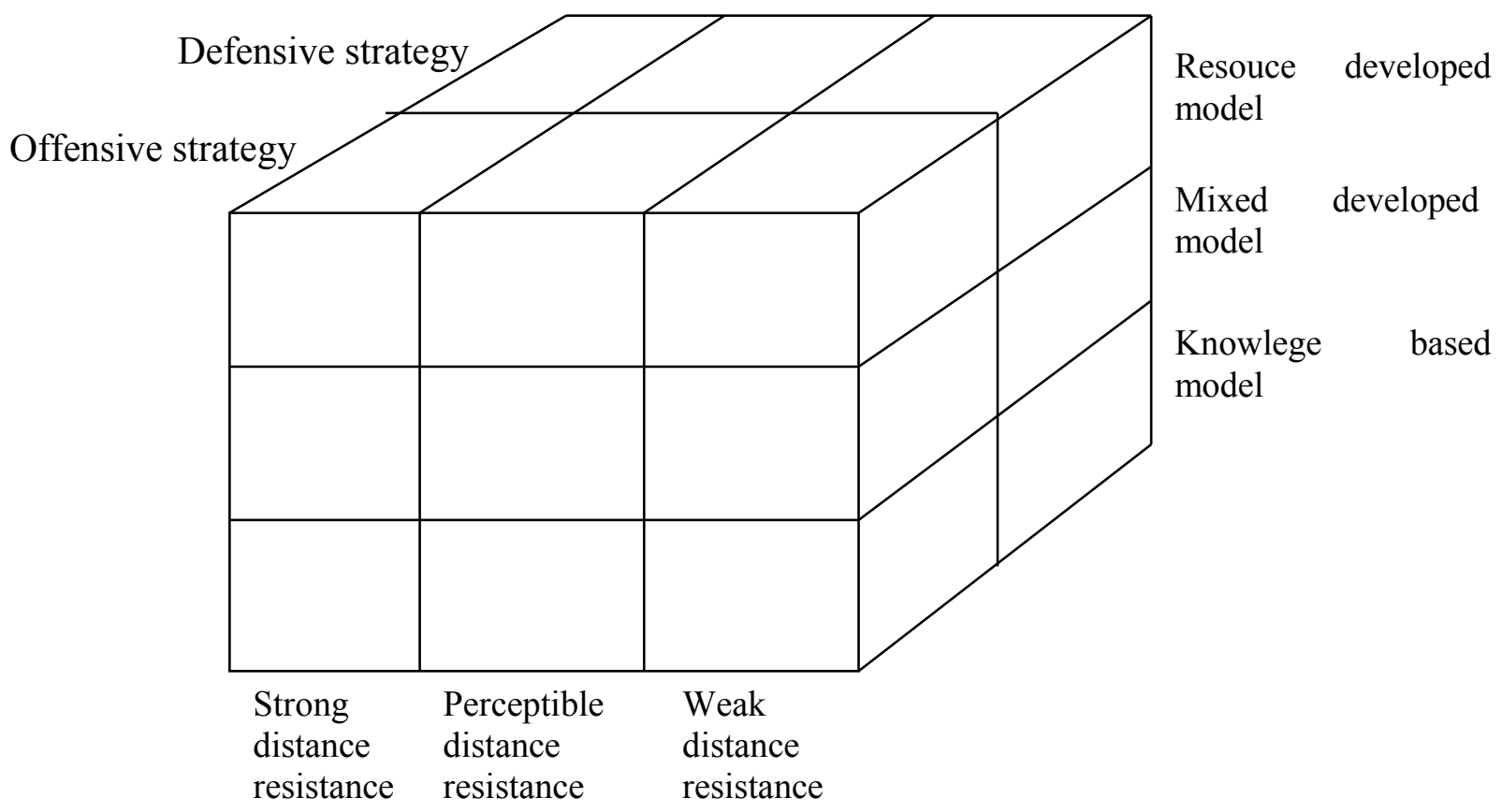

Fig. 1: Simplified three-dimensional model of areas of choice of corporate development strategy (development of the national economy)

Source: own development. 
The influence of the market environment forces us to choose between defensive and offensive strategy, which is reflected in the third dimension of the model.

The presented model makes it possible to formulate strategic goals and methods of their achievement, based on the answers to the following key questions:

- what is the resistance of distance and to what extent it can affect the ability of the economy (enterprise) to develop dynamically;

- what is the existing model of economic development and how it is able to ensure the competitiveness of the economy (enterprise) in the global market;

- what type of relations with the environment (offensive or defensive) will allow to use the potential of the economy (enterprise) with the highest efficiency and the lowest risks in the strategic time horizon.

\section{Conclusion}

Further research on the subject of the article is promising in the direction of developing a methodology for determining the share of each of the four causes of international trade in terms of total international trade of individual countries and in terms of bilateral trade between different pairs of countries. An important area of further research is the evaluation of DR for various benefits in bilateral trade between countries.

The presented approach to the choice of corporate development strategy / development of the national economy focuses on three dimensions. In practice, its use will require not only the specification of each of them, but also taking into account other dimensions that may be associated with the specific conditions of the national economy or its individual industries. This is even more true at the corporate level. In this case, the choice of development strategy depends on a much wider range of determinants, which include, in particular, the company's market position, industry structure and nature of competition, the level of integration with the environment (cooperation network), the size of the enterprise, its level of innovation and etc. $[4,9,16,22,25]$.

The level of the economy is determined by the level of competitiveness of companies. Companies that belong to the group of leaders or contenders have a significant advantage over imitators and specialists, as they have much greater financial, intellectual and material resources. These companies are actively engaged in innovation activity and use an offensive strategy in the market in order to strengthen their competitive position and increase market share.

Defensive strategy is used by imitators to survive in the market. The imitator's strategy is based on the transferred innovation and is forced. The imitators are forced to implement changes under the pressure of the leaders and contenders activities in the field of innovation, so their strategy can be identified defensive.

Based on the presented model, it is possible to identify some of its "spatial" components (eg, defensive strategy with low resistance to space and in a knowledge-based economy). The boundaries of each of these "spatial blocks" determine the direction, scope and structure of further research related to the problems of choosing a development strategy. Detailing and concretization of these areas of activity, according to the authors, lies in the plane of very relevant and important issues.

\section{References:}

[1] Anderson J., Wincoop E. (2003) Gravity with Gravitas: A Solution to the Border Puzzle, The American Economic Review. Vol. 93. No 1. P. 170-192.

[2] Anderson, J. (1979) A Theoretical Foundation for the Gravity Equation. American Economic Review 69(1): 106-16.

[3] Anderson, J. (2011) The Gravity Mode,. Annual Review of Economics 3(1): 133-60.

[4] Andreini D., Bettinelli C. (2017) Business model innovation: From systematic literature review to future research directions, J. Manag. Gov. 21, 785-792.

[5] Antonelli, C., Feder, C. (2021). Schumpeterian loops in international trade: the evidence of the oecd countries, Journal of Evolutionary Economics, 31, 799-820. https://doi.org/10.1007/s00191-021-00725-8

[6] Armington Paul, (1969) A Theory of Demand for Products Distinguished by Place of Production, IMF Staff Papers 16, pp.159-178. https://doi.org/10.2307/3866403

[7] Balassa B. (1963) An empirical demonstration of classical comparative cost theory / Balassa B. // The Review of Economics and Statistics. 1963. - Vol. 45, No. 3. - P. 231 - 238.

[8] Brazelton R. (1977) Samuelson's Principles of Economics in 1948 and 1973, The Journal of Economic Education, 8:2,115117, DOI: 10.1080/00220485.1977.10845445

[9] Doherty A.M. (2007) The internationalization of retailing: Factors influencing the choice of 
franchising as a market entry strategy, International Journal of Service Industry Management, Volume 18, Issue 2.

[10] Elmslie, B. (2018). Retrospectives: Adam Smith's Discovery of Trade Gravity, Journal of Economic Perspectives, 32 (2): 209-22.DOI: 10.1257/jep.32.2.209

[11] Ethier, W. (1982) National and International Returns to Scale in the Modern Theory of International Trade, „American Economic Review" 1982, inr 3, s. 389-405.

[12] Galanis, S. (2018). Six easy models of international trade theory. A concise introduction to the theory of international trade. London, Polyolvos, $99 \mathrm{p}$.

[13] Gaspar, J.M. (2020). Paul Krugman: contributions to Geography and Trade. Letters in Spatial and Resource Sciences, 13, 99-115. https://doi.org/10.1007/s12076-020-00247-0

[14] Harky J. (March 1974), Mercantilism: Past, Present and Future, The Manchester School, 42: $\quad$ 1-17, doi:10.1111/j.14679957.1974.tb00098.x

[15] Herlitz L. (1964) The concept of mercantilism, Scandinavian Economic History Review, 12:2, 101120, DOI: $10.1080 / 03585522.1964 .10407639$

[16] Hosseini A.S., Soltani S., Mehdizaden M. (2018) Competitive Advantage and Its Impact on New Product Development Strategy (Case Study: Toos Nirro Technical Firm), Journal of Open Innovation: Technology, Market, and Complexity, 4(2), 17.

[17] Krugman P. R. (1979), Increasing Returns Monopolistic Competition and International Trade, Journal of International Economics, 9, 469-479.

[18] Krugman P. R. (1980), Scale Economies, Product Differentiation and the Pattern of Trade, The American Economic Review, 70, 950-959.

[19] Krugman, P. (1981), Intra-industry Specialization and the Gains from Trade, Journal of Political Economy, Vol. 91, pp. 8396.

[20] Leamer E. (1995) The Heckscher-Ohlin Model in theory and practice. Princeton Studies in International Finance, No.77. 60 p.

[21] Levy, D. and Peart, S. (2009) Soviet Growth \& American Textbooks. Available at SSRN: https://ssrn.com/abstract=1517983 or http://dx.d oi.org/10.2139/ssrn.1517983

[22] Li Y., Guohui S., Eppler M. (2008) Making strategy work: a literature review on the factors influencing strategy implementation.
ICA Working Paper 2/2008 https://doc.rero.ch/record/8916/files/wpca0802. pdf

[23] Linder, S. (1961) An Essay on Trade and Transformation. New York: John Wiley \& Sons. Pp. 167.

[24] Meoqui, J. (2014). Reconciling Ricardo's Comparative Advantage with Smith's Productivity Theory, Economic Thought 3 (2), 21-37.

[25] Nyangara A.C., Patrick B.O., Oima D. (2015) Factors influencing choice of strategic management modes of small enterprises, Journal of Innovation and Entrepreneurship volume 4, Article number: 4.

[26] Ohlin G. (1933). International and Interregional Trade. London.

[27] Pomfret R. (2016). International Trade: Theory, Evidence And Policy. Princeton University Press; 496 p.

[28] Posner, M. (1961) International Trade and Technical Change, Oxford Economic Papers, N.S., Vol. 13, Oxford, pp. 323-341.

[29] Rassekh, F. (2015) Comparative Advantage in Smith's Wealth of Nations and Ricardo's Principles: A Brief History of Its Early Development. History of Economic Ideas, 23 (1), 59-75.

[30] Ricardo, David. 1817 [1981]. On the Principles of Political Economy and Taxation. Cambridge University Press

[31] Samuelson, P. (1948) Economics, an Introductory Analysis, First Edition, Fifth Impression. New York: McGraw-Hill, Inc.,

[32] Samuelson, P. (1952) Economic Theory and Mathematics - An Appraisal, American Economic Review, 42(2), pp. 56-66.

[33] Sato, H. (2021). A two-country, threecommodity Ricardian trade model with Keynesian unemployment. Metroeconomica. 72, 286-308. https://doi.org/10.1111/meca. 12320

[34] Schiliro D. (2012) Knowledge-Based Economies And The Institutional Environment. Theoretical and Practical Research in Economic Field, Volume III, Issue 1(5), pp. 4250. DOI: $10.2478 / \mathrm{v} 10261-012-0004-3$

[35] Schumacher, R. (2015) Adam Smith's 'Two Distinct Benefits' from Trade: The Dead End of 'Vent-for-Surplus' Interpretations. History of Political Economy, 47(4), 577-603.

[36] Senga S., Fujimoto M., Tabuchi T. (2017) Ricardo and International Trade. London and New York: Routledge. 276 p. 
[37] Smith, Adam. 1776 (2003) An Inquiry into the Nature and Causes of the Wealth of Nations. New York: Bantam Books.

[38] Smith K. (2007) Innovation and Growth in Resource-based Economies. CEDA Growth: Competing from Australia, No 58, pp. 50-58.

[39] Strange, G. (2020) Debating Free International Trade. American Journal of Economics and Sociology, 79 , $25-$ 47. https://doi.org/10.1111/ajes. 12310

[40] Tinbergen J. (1966) Shaping the World Economy: Suggestions for an International Economic Policy, The Economic Journal. Vol. 76. Working Paper No 301. P. 92-95.

[41] Vernon, R. (1966) International Investment and International Trade in the Product Cycle, The Quarterly Journal of Economics, Volume 80, Issue 2, Pp. 190-207, https://doi.org/10.2307/1880689

Contribution of Individual Authors to the Creation of a Scientific Article (Ghostwriting Policy)

Jerzy Stadnicki analyzed the scientific literature and developed the concept that there are only four causes of international trade Oleksandr Oksanych developed a three-dimensional model of areas of choice of corporate development strategy

\section{Sources of Funding for Research Presented in a Scientific Article or Scientific Article Itself}

The research, the results of which are presented in the article, were financed by the University of Technology in Kielce

\section{Creative Commons Attribution License 4.0} (Attribution 4.0 International, CC BY 4.0) This article is published under the terms of the Creative Commons Attribution License 4.0 https://creativecommons.org/licenses/by/4.0/deed.en US 